\title{
Experimental investigation on the burning behaviors of thin-layer transformer oil on a water layer
}

Zhao, J., Zhang, J., Chen, CH., Huang, H., \& Yang, R. (2020). Experimental investigation on the burning behaviors of thin-layer transformer oil on a water layer. Process Safety and Environmental Protection, 139, 8997. https://doi.org/10.1016/j.psep.2020.04.016

Link to publication record in Ulster University Research Portal

\section{Published in:}

Process Safety and Environmental Protection

Publication Status:

Published (in print/issue): 01/07/2020

DOI:

10.1016/j.psep.2020.04.016

\section{Document Version}

Author Accepted version

\section{General rights}

Copyright for the publications made accessible via Ulster University's Research Portal is retained by the author(s) and / or other copyright owners and it is a condition of accessing these publications that users recognise and abide by the legal requirements associated with these rights.

\section{Take down policy}

The Research Portal is Ulster University's institutional repository that provides access to Ulster's research outputs. Every effort has been made to ensure that content in the Research Portal does not infringe any person's rights, or applicable UK laws. If you discover content in the Research Portal that you believe breaches copyright or violates any law, please contact pure-support@ulster.ac.uk. 


\section{Experimental investigation on the burning behaviors of thin-layer transformer oil on a water layer}

Jinlong Zhao ${ }^{\mathrm{a}, b^{*}}$, Jianping Zhang ${ }^{\mathrm{b}}$, Changkun Chen ${ }^{\mathrm{c}}$, Hong Huang ${ }^{\mathrm{d}}$, Rui Yang ${ }^{\mathrm{d}}$

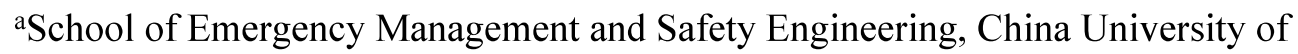
Mining \& Technology, Beijing, 10084, China

${ }^{b}$ FireSERT, Belfast School of Architecture and the Built Environment, Ulster

University, Newtownabbey, BT370 QB, United Kingdom

'Institute of Disaster Prevention Science \& Safety Technology, Central South

University, Changsha, 410075, China

${ }^{d}$ Institute of Public Safety Research, Department of Engineering Physics, Tsinghua

University, Beijing, China

*Corresponding author at:

School of Emergency Management and Safety Engineering, China University of

Mining \& Technology-Beijing, 100084, China; E-mail: 15210567787@163.com.

(Jinlong Zhao) 


\section{Experimental investigation on the burning behaviors of thin-layer transformer oil on a water layer}

Jinlong Zhao a,b* , Jianping Zhang ${ }^{\mathrm{b}}$, Changkun Chen ${ }^{\mathrm{c}}$, Hong Huang ${ }^{\mathrm{d}}$, Rui Yang ${ }^{\mathrm{d}}$

a. School of Emergency Management and Safety Engineering, China University of

Mining \& Technology, Beijing, 10084, China

b. FireSERT, Belfast School of Architecture and the Built Environment, Ulster

University, Newtownabbey, BT370 QB, United Kingdom

c. Institute of Disaster Prevention Science \& Safety Technology, Central South

University, Changsha, 410075, China

d. Institute of Public Safety Research, Department of Engineering Physics, Tsinghua

University, Beijing, China

Abstract: This paper examines experimentally the burning behaviors of thin-layer transformer oil on a water layer. A series of transformer oil pool fire experiments with different initial fuel thicknesses was performed. The burning process, burning rate, liquid temperature and radiative heat flux were measured. The experimental results show that the whole process can be divided into five typical phases: (1) rapid growth burning, (2) steady burning, (3) short boilover burning, (4) continuous boilover and (5) fire decay. The appearance of the middle three phases (2-4) depends on initial fuel thickness. The steady burning rate is found to be independent of the fuel thickness but slightly higher than that of burning without a water layer, because of the decrease in the boiling point of the fuel-water mixture. A critical fuel thickness was found to determine whether continuous boilover or short boilover will occur. The results also show the intensity of the initial boilover increases with increasing fuel thickness but the intensity of subsequent boilover of thin-layer burning can surpass that of thicklayer burning for some cases. A linear correlation was found between the time to boilover and fuel initial thickness in agreement with literature findings. The present results are of practical importance in situ-burning and thermal hazard analysis for fire accidents due to leakage of liquid fuels on water.

Key words: thin-layer burning, boilover intensity, burning rate, critical thickness 


\section{Introduction}

During the fuel processing, transportation and storage, leakage of liquid fuels can pose a great threat to the environment due to a large pollution area, especially for the marine environment (Sivagami et al., 2019; Bullock et al., 2019). The burning of thinlayer fuels on the water surface is of great research interest in order to eliminate or minimize the water pollution because of fuel leakage, known as in-situ burning (Bullock et al., 2019; Rojas-Alva et al., 2019). Thin-layer burning accidents in industrial parks have also been reported in ( $\mathrm{Li}$ et al., 2015; Zhao et al., 2016). For example, there is a serious leakage fire accident after the collision for Sanchi on 6 January 2018, in which the oil tanker sank to the sea containing approximately 2000 tons fuel (Qiao et al., 2019).

In fuel leakage fire accidents, the thickness of the fuel layer is usually in the order of millimeters because there is no horizontal restriction (Drysdale, 2011; Zhao et al., 2019). As a result, the heat transfer process between the water layer and the fuel layer has a significant effect on the burning behaviors. Under certain conditions, the burning of a thin fuel layer can develop into a special phenomenon known as boilover characterized by violent burning (Laboureur et al., 2013; Koseki et al., 2006). The occurrence of boilover can change significantly the heat transfer process and increase the fuel burning rate. On the other hand, the appearance of boilover poses a great hazard to the nearby persons or equipment because of high-level irradiance in leakage fires (Ferrero et al., 2007).

Extensive research has been undertaken over last decades on thin-layer burning because of the serious consequences in fuel leakage on the sea (Buist et al., 1999; Fingas and Punt, 2000). Fan et al. (1995) conducted small-scale $(\sim 20 \mathrm{~cm})$ oil burning experiments on a water surface and divided the main burning process into three periods: a quasi-steady period, a boilover premonitory period and a boilover period. In the boilover period, the flame height and burning rate are much higher than those in the quasi-steady period. Kong et al. (2017) conducted a series of small-scale $(\mathrm{D}=10 \mathrm{~cm}, 15 \mathrm{~cm}$ and $20 \mathrm{~cm}$ ) boilover fire experiments and divided the whole burning phase into four typical stages: the growth stage, quasi-steady stage, boilover stage and 
decay stage. They observed that the boilover intensity depended on the initial fuel thickness and burning diameter (Kong et al., 2017). Ferrero et al. (2006) conducted large-scale $(D=1.5 \mathrm{~m}, 3 \mathrm{~m}, 6 \mathrm{~m})$ gasoline and diesel pool fires experiments on a water surface and found that the phenomenon of boilover only occurred for diesel. In a more detailed study of thin-layer boilover, Arai et al. (1990) conducted small-scale thinlayer burning experiments with different pan diameters $(4.8 \mathrm{~cm}, 9.8 \mathrm{~cm}$ and $20.3 \mathrm{~cm})$ using 16 types of fuels. They concluded that the boilover only occurred with fuels whose boiling temperature was higher than the water boiling point. Garo et al. (1994) also conducted thin-layer burning experiments and found the nuclear boiling at the interface resulted in the thin-layer boilover. They also obtained that the boilover intensity depended on burning diameter and initial fuel thickness. Xiao et al. (2016) found the blue whirl during the fuel burning on a water surface. Brogaard et al. (2014) analyzed the fuel thickness effect on burning phenomenon and parameters of some pool fire experiments on a water surface for n-Octane, Dodecane and oil. They found that the burning efficiency would increase with the thickness increasing because of boilover for oil and keep nearly 100\% for the other two fuels (Brogaard et al., 2014). More recently, Gelderen et al. (2017) further verified this founding for some kind of crude oils. Alva et al. (2018) found that the pumice stones could not enhance oil burning efficiency on a water surface. The environmental effects such as wind (Ping et al., 2018; Kong et al., 2019), ice (Farahani, 2015) and weathering (Fritt-Rasmussen et al., 2013) on the boilover phenomenon were also investigated using small-scale experiments.

Apart from the above experiments, numerical models have also been developed to explain the variation of the thin-layer burning rate and to predict the time to boilover. Twardus and Brzustowski (1981) proposed a one-dimensional conduction model, simulating the heat transfer process in the fuel layer. Subsequently, one layer and two layers (oil layer and water layer) conduction transient models were developed to calculate the heat loss of the fuel layer by Arai et al. (1990) and Garo et al. (1999), respectively. Inamura et al. (1992) developed a transient model, considering conduction and radiative absorption by the fuel layer. In addition, the heat convection 
in the liquid layer was incorporated into the transient model by Kozanoglu et al. (2008). Hristov et al. (2004) further analyzed the commonly used models and discussed the corresponding application range.

These studies have clearly shown that the burning rate, flame height and radiation during boilover are much larger than those during steady burning. However, most of these studies are based on small-scale experiments and the experimental data of largescale burning is limited because of the difficulties in measuring accurately the burning rate for large-scale burning experiments, as verified by Ferrero et al. However, one would expect that the burning behaviors including boilover will change greatly from small-scale burning experiments to large-scale real accidents (Ferrero et al., 2006; Arai et al., 1990). Moreover, whilst it is evident that the initial fuel thickness has an effect on thin-layer burning, the detailed reason behind this effect is still unclear due to the occurrence of the boilover and needs to be explored further in detail. More importantly, the burning behaviors after the initial boilover for thin-layer burning in which multiple subsequent boilover may occur, have never been studied systematically to the best knowledge of the authors, which can be of great importance in situ-burning of leaked fuels on water.

To close this knowledge gap, this work aims to examine and characterize experimentally the burning behaviors of thin-layer transformer oil with different initial thicknesses on a water surface. The whole burning process is presented and the effects of the water layer on the burning behaviors including burning rate, flame height and radiation are analyzed in detail and the critical parameters determining the occurrence of boilover and its start time are also discussed. The present results will be of practical use in situ-burning and thermal hazard analysis in leakage fire accidents.

\section{Experimental setup}

All experiments were conducted in a large hall. The doors and windows of the hall were all closed but not sealed during the experiments, so the wind effect was not considered in the experiments. The overall schematic of the experimental setup is shown in Fig.1. In the experiments, a stainless pan with a side wall of $10 \mathrm{~cm}$ was used and the inner diameter is $60 \mathrm{~cm}$. For this diameter, the burning is mainly controlled by 
the radiative heat feedback from the flame to the fuel surface, similar to actual fire accidents (Hamins et al., 1994). The pan was placed on the top of a load cell (precision: 0.1g, range: 0-60 kg) to record the real time mass loss of the oil. The burning rate can be calculated based on the residual mass variation in the pan. At here, it is should be noted that the burning rate during the boilover includes the fuel evaporation part, fuel projective part and water evaporation part. A fireproof board was placed between the load cell and the pan to protect the load cell. A thermocouple (tip of $1 \mathrm{~mm}$, resolution $\pm 1 \mathrm{~K}$ ) array was placed inside the pan at $1,2,3,4$, and $5 \mathrm{~cm}$ from the pan bottom surface as shown in Fig. 1 to measure the temperature of the liquid fuel and its vapor near the fuel surface. Another set of 10 thermocouples (tip of $5 \mathrm{~mm}$, uncertainties $\pm 5 \mathrm{~K}$ ) was positioned evenly above the pan in the flame region at a $15 \mathrm{~cm}$ interval to measure the flame temperature and the first one is $15 \mathrm{~cm}$ to the pan bottom surface. Radiative heat flux was measured by two water-cooled heat flux meters (SBG01, Range: 0 50 kW/ $\mathrm{m}^{2}$ ) with a nearly hemispherical wide view angle. One was positioned at about five times of the pool diameter away from the pool center. The other was positioned closer to the pan around two times of the pool diameter. The heat flux meters were located at $0.6 \mathrm{~m}$ to the pan bottom surface in vertical direction. Two cameras were used from different directions to record the flame contour mainly the flame height. Videos of the flames were converted to a series of binary pictures and then the flame height can then be determined based on a certain scale, which is common used in some literatures (Ping et al., 2018; Tao et al., 2013). The temperature signal and heat flux signal were simultaneously recorded by an acquisition module (Fluke 2680 Series Data Acquisition Systems).

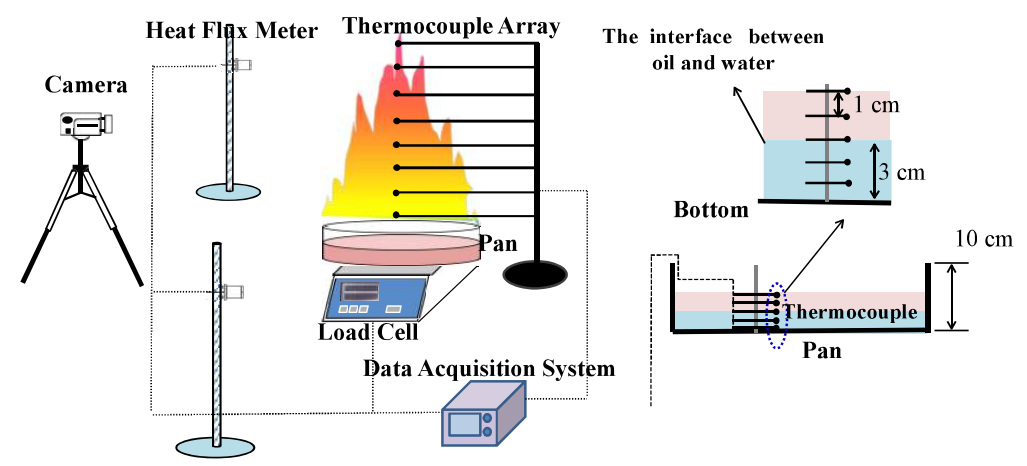

Fig. 1. Schematic of experimental setup and the detail layout of thermocouples 
Prior to the tests on a water layer, we firstly performed tests with only the transformer oil to establish the burning characteristics of the fuel. For the tests with a water layer, water was injected into the pan before the fuel. The thickness of the water layer was set as $3 \mathrm{~cm}$, which was chosen by considering the range of the load cell and preliminary experiments which show that the temperature at the bottom of the pan remained at ambient temperature for the whole burning process. In some experiments with a thick fuel layer, it was found that a large amount of fuel was left in the pan after the extinguishment of the fire. In this case, the fuel was re-ignited after the water has cooled down to ambient conditions to obtain additional test data. The detailed specifications of the experimental condition are shown in Table 1.

The indoor temperature was $29 \pm 3^{\circ} \mathrm{C}$ and the humidity remained at around $56 \pm 10 \%$ during the experiments. In the tests, about $10 \mathrm{~mL}$ heptane was injected onto the surface of the fuel which was ignited by a butane hand torch to initiate the combustion of the transformer oil.

Table 1. Specification of the experimental conditions

\begin{tabular}{ccc}
\hline Test number & Fuel thickness $(\mathrm{mm})$ & Water Thickness $(\mathrm{mm})$ \\
\hline Test 1 & 10 & 0 \\
Test 2 & 30 & 0 \\
Test 3 & 50 & 0 \\
Test 4 & 30 & 30 \\
Test 5 & 20 & 30 \\
Test 5-1 & 11.3 & 30 \\
Test 5-2 & 8.5 & 30 \\
Test 5-3 & 6.3 & 30 \\
Test 6 & 10 & 30 \\
Test 6-1 & 7.0 & 30 \\
Test 7 & 7.5 & 30 \\
Test 8 & 5.0 & 30 \\
\hline
\end{tabular}




\section{Result and discussion}

\subsection{Burning phenomenon}

\subsubsection{Burning process without water layer}

Without a water layer, the fuel was burning quietly, and no sound was detected during the whole burning process. Test-3 is taken as an example to describe the burning process in detail and the burning process and the flame height as a function of time are shown in Fig.2. It can be observed that the burning rate increases with time, corresponding to an increase of flame height at the initial stage. Subsequently, the burning rate and flame height become nearly constant for a relatively long period of time. Near the end of the test, both the burning rate and flame height decrease because all the fuel has been consumed. Based on the above variations, the whole burning can be simply divided into three phases: (I) rapid growth, (II) steady burning and (III) fire decay, which is in good agreement with those observed in a large kerosene pool fire reported by Lu et al. (2020) and a large diesel pool fire by Chatris et al. (2001).
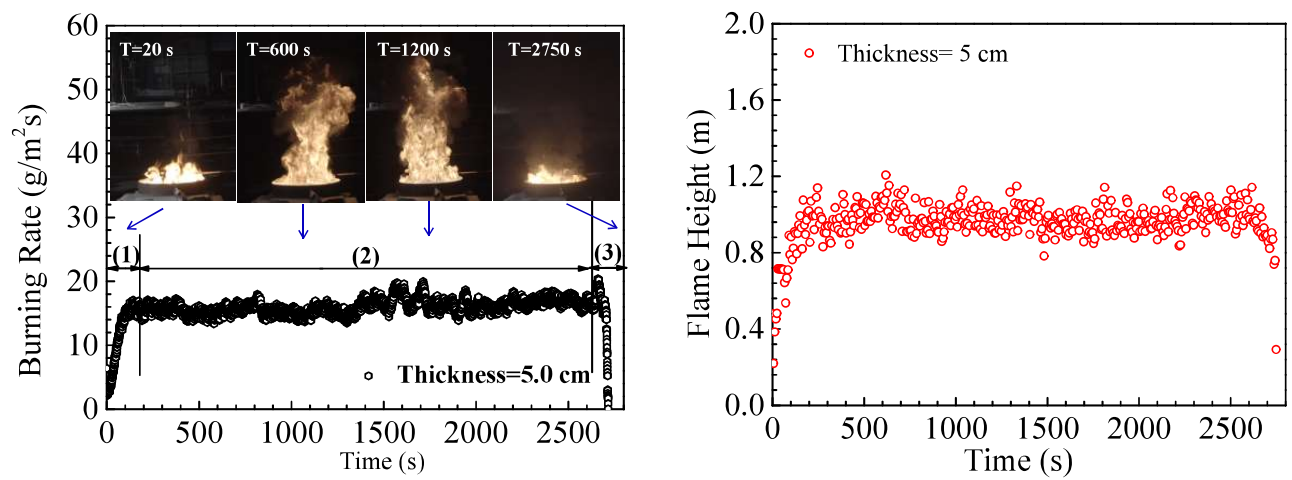

Fig. 2. The whole burning process and the flame height as a function of time

\subsubsection{Burning process with a water layer}

In this case, cracking sound can be heard for the whole burning process, which may indicate the presence of bound water in the fuel. The phenomenon of boilover can be clearly seen, as indicated by violent burning and increased flame height as shown in Fig. 3, which presents the whole burning process and flame height as a function of time for the thick fuel layer in Test-4. 

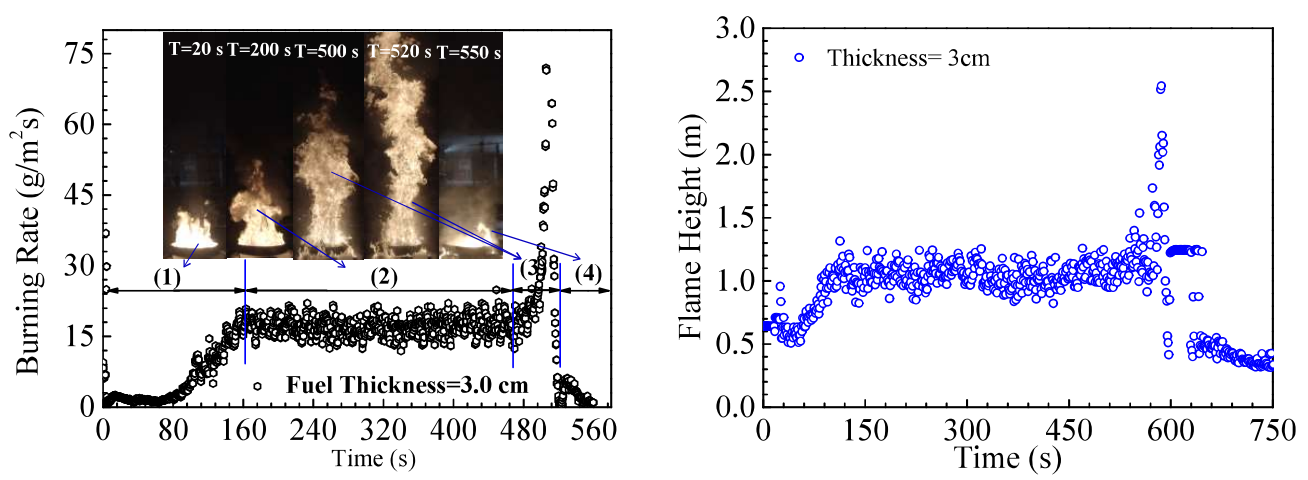

Fig. 3. The whole burning process and flame height as a function of time for

Test-4

The burning behaviors in Fig.3 are similar to those of burning without the water layer, except for the boilover period. Before the start of boilover, the cracking sound becomes more obvious and a small amount of fuel was ejected, consistent with the observations in Fan's experiments (1995). During the boilover process, the mass burning rate and flame height increase significantly. For example, the maximum burning rate is about four times of the steady burning rate and the maximum flame height about two times of the steady flame height in Test-4. Moreover, we observed that some of the fuels were pushed out of the pan and were burning on the ground, seen pictures in Fig.3. Boilover sustains for around 30s and then quickly decays until extinguishment. The extinguishment caused by boilover decreases the burning duration. For example, it decreases from approximately 1700s in Test 2 to 520s in Test 4, which implies that a large amount of unburned fuel was left in the pan after fire extinguishment in Test-4.

In experiments with small initial fuel thicknesses of $7.5 \mathrm{~mm}$ and $5 \mathrm{~mm}$, the burning behaviors show a different trend and the boilover occurred for multiple times until all the fuel was burnt out. The detailed burning process of Test-7 is shown in Fig.4. For the thin-layer burning, the steady burning phase is not obvious. The burning rate and flame height show significant fluctuations because of the occurrence of boilover. During the boilover, the flame and the burning rate both increase greatly in the initial period and then decay so quickly that gives an illusion of fire extinguishment. Understand this phenomenon is important as in actual fire accidents, great caution 
must be taken when approaching the fuel following boilover, because even though the fire may seem to have extinguished, re-ignition of the remaining fuel and subsequent boilover could still occur.
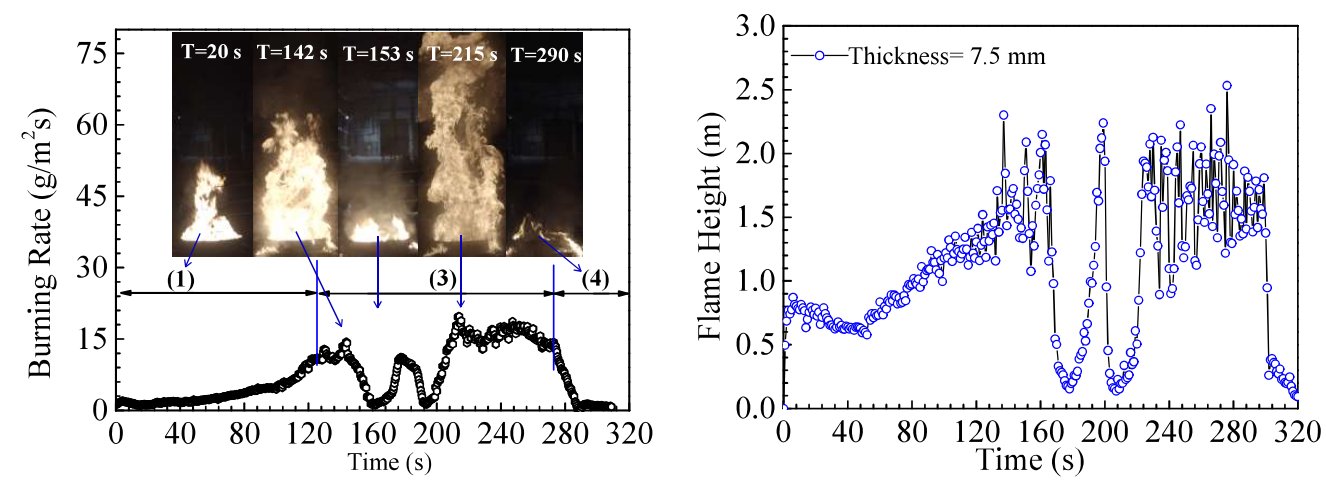

Fig. 4. The whole burning process and flame height as function of time for Test7

The burning phenomenon observed clearly shows that the burning behaviors are closely related to the initial fuel thickness. Considering the above burning phenomenon appeared in the experiments, the whole burning process can be divided into five phases: (I) rapid growth phase, (II) steady burning phase, (III) short boilover burning phase, (IV) continuous boilover burning phase and (V) fire decay phase. The appearance of steady burning, short boilover burning and continuous boilover burning depends on the initial fuel thickness. The number of boilover occurrences observed for all tests are given in Table 2, along with durations of burning phases and the burning efficiency (the ratio between the mass of fuel burned and the initial mass).

Table 2. The detail information on the burning phase, sustain time and boilover time

\begin{tabular}{|c|c|c|c|c|c|}
\hline Test & $\begin{array}{l}\text { Burning phases } \\
\text { (corresponding time, s) }\end{array}$ & $\begin{array}{l}\text { Initial } \\
\text { mass, g }\end{array}$ & $\begin{array}{l}\text { Final } \\
\text { mass, } \mathrm{g}\end{array}$ & $\begin{array}{c}\text { Burning } \\
\text { efficiency, \% }\end{array}$ & $\begin{array}{l}\text { Boilover } \\
\text { times }\end{array}$ \\
\hline 4 & $\begin{array}{l}\text { I (98 s); II (515 s); } \\
\text { III (21 s) ; V(26 s). }\end{array}$ & 7574 & 4315 & 43.03 & 1 \\
\hline 5 & $\begin{array}{l}\text { I (148 s); II (339 s); } \\
\text { III (19 s ); V(16 s). }\end{array}$ & 5022 & 2803 & 44.19 & 1 \\
\hline 6 & $\begin{array}{l}\text { I (110 s); II (32 s); } \\
\text { III (34 s ); V(16 s). }\end{array}$ & 2623 & 1740 & 33.66 & 1 \\
\hline 7 & $\begin{array}{l}\text { I (92 s); II (17 s); } \\
\text { IV (170 s ); V(21 s). }\end{array}$ & 1928 & -300 & $\sim 100$ & 16 \\
\hline 8 & $\begin{array}{c}\text { I (103 s); IV (108 s ); } \\
\text { V(34 s). }\end{array}$ & 1315 & -220 & $\sim 100$ & 9 \\
\hline
\end{tabular}


Table 2 shows that there is a critical fuel thickness $(7.5 \sim 10 \mathrm{~mm})$ which determines whether continuous boilover or short boilover will occur. The measured final mass is negative in Tests 7 and 8, indicating that some water evaporated or ejected during boilover. After the fire extinguishment in Tests 7 and 8, not residual fuels were observed in the pan. Therefore, the burning efficiency has been improved greatly due to the continuous occurrence of boilover. In comparison, the burning efficiency is much smaller for thick-layer fuels due to sudden extinguishment after boilover. As a result, increasing the fuel thickness alone cannot improve the burning efficiency in situ burning.

\subsection{Burning rate}

The burning rate varies significantly during different burning phases because of the change in the heat feedback from the flame and heat transfer process in the liquid layer. In the steady burning phase, the burning rate is nearly constant and can sustain for a long period of time if the fuel thickness is sufficiently large. Because the steady burning phase is closely related to the boilover intensity and the time to boilover, the steady burning rate is analyzed, and the results are shown in Fig.5.

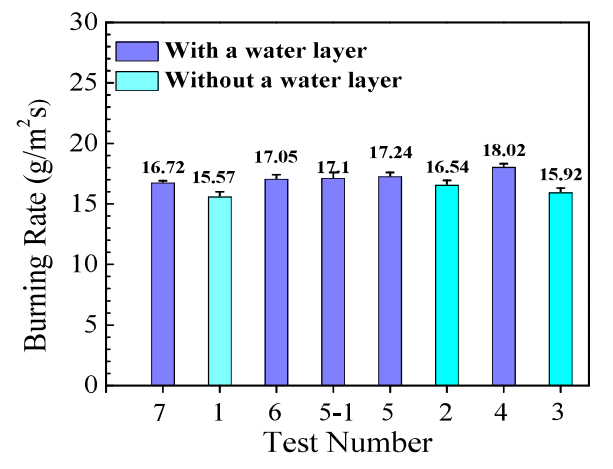

Fig.5. The steady average burning rate for the experiments

Figure 5 clearly shows that the steady burning rate is independent of the initial fuel thickness. The steady burning rate on a water layer is slightly larger than the one without a water layer with an average difference of $1.22 \mathrm{~g} / \mathrm{m}^{2} \mathrm{~s}$. In order to explain this phenomenon, the heat transfer process of the steady burning phase is analyzed and shown in Fig.6. 

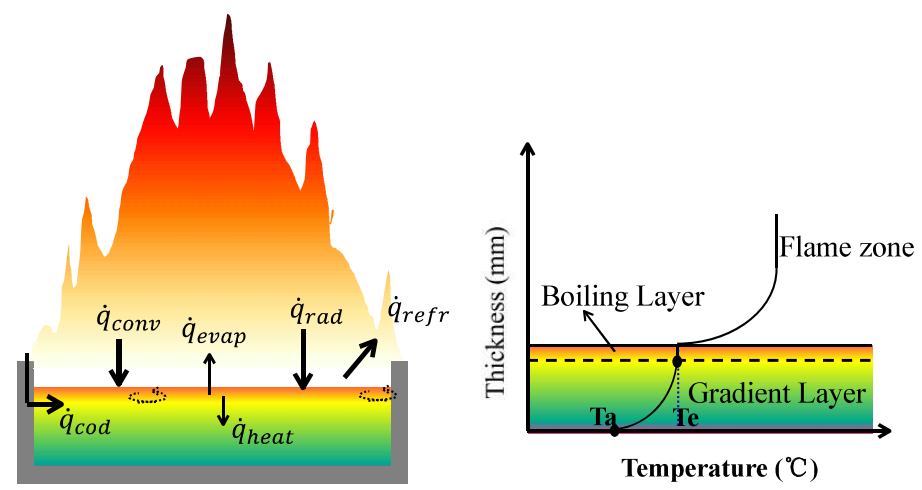

Fig. 6. The heat transfer process for pool fires (Hamins et al., 1994) and the temperature profile near the liquid surface

As shown in (Suo-Anttila et al., 2009), the radiative heat feedback from the flame to the fuel surface is mainly absorbed by the upper fuel layer $(\sim 3 \mathrm{~mm})$. The liquid layer can be divided into two layers (boiling layer and gradient layer) based on vertical temperature profile (Zhao et al., 2018; Vali et al., 2014), shown in Fig.6. In the boiling layer, the fuel is vaporized after absorbing the heat from the flame. In the gradient layer, the absorbed heat is used to increase the liquid temperature and the heat transfer process is mainly by the heat conduction in this layer (Vali et al., 2014). So the detail burning rate can be expressed as:

$$
\begin{gathered}
L_{v} \mathrm{~m}^{\prime}=\dot{q}_{\text {evap }} \\
\dot{q}_{\text {evap }}=\dot{q}_{\text {conv }}+\dot{q}_{\text {rad }}+\dot{q}_{\text {cod }}-\dot{q}_{\text {ref }}-\dot{q}_{\text {heat }}
\end{gathered}
$$

where $L_{v}$ is latent heat of evaporation of the oil, $\dot{q}_{\text {cod }}, \dot{q}_{\text {rad }}$, and $\dot{q}_{\text {conv }}$ are the heat conduction from the side walls to the liquid layer, the flame radiative heat feedback and the heat convection between the flame and the liquid surface, respectively. $\dot{q}_{r e f}$ is the reflected radiation part by the fuel surface, which is usually neglected in pool fires (Hamins et al., 1994). $\dot{q}_{\text {heat }}$ is the heat conduction part in the gradient layer, which increases the liquid temperature including the fuel and water temperature as burning on a water surface. $\dot{q}_{\text {evap }}$ is the heat that directly used for the fuel evaporation. For a pool fire burning (D>20cm), the burning rate is mainly controlled by the radiative heat feedback from the flame to the fuel surface (Hamins et al., 1994) 
and the evaporation rate can be written as:

$$
L_{v} \mathrm{~m}^{\prime}=\sigma \varepsilon F T_{f}^{4}-\dot{q}_{\text {heat }}
$$

where $F$ is a geometric view factor, related to the flame shape. $\varepsilon$ is the flame emissivity. $T_{f}$ is the flame temperature. Clearly, the burning rate is related to flame temperature and flame height based on Eqs.(1-3). In the experiments, the flame height and flame temperature were measured and are shown in Fig. 7.
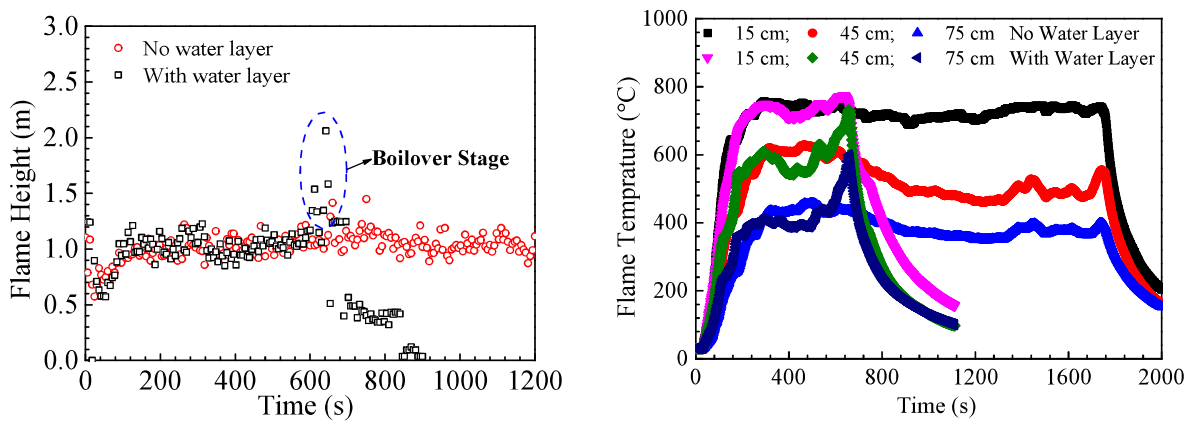

Fig. 7. The measured transient flame height and flame temperature as a function of time for Tests 2 and 4

As shown in Fig.7, the water layer has no effect on the flame height and flame temperature at the steady burning phase, implying that the radiative heat feedback remains nearly constant. So the heat conduction part $\left(\dot{q}_{\text {heat }}\right)$ in the gradient layer needs to be further analyzed. Based on the heat conduction model by Vali et al.(2014), the heat conduction transfer rate depends mainly on the temperature at the interface of the boiling and gradient layers and the conductivity of the liquid in the gradient layer. Figure 8 presents the temperature histories measured by the thermocouples inside the pan (see Fig.1) for Test 3 and Test 5.
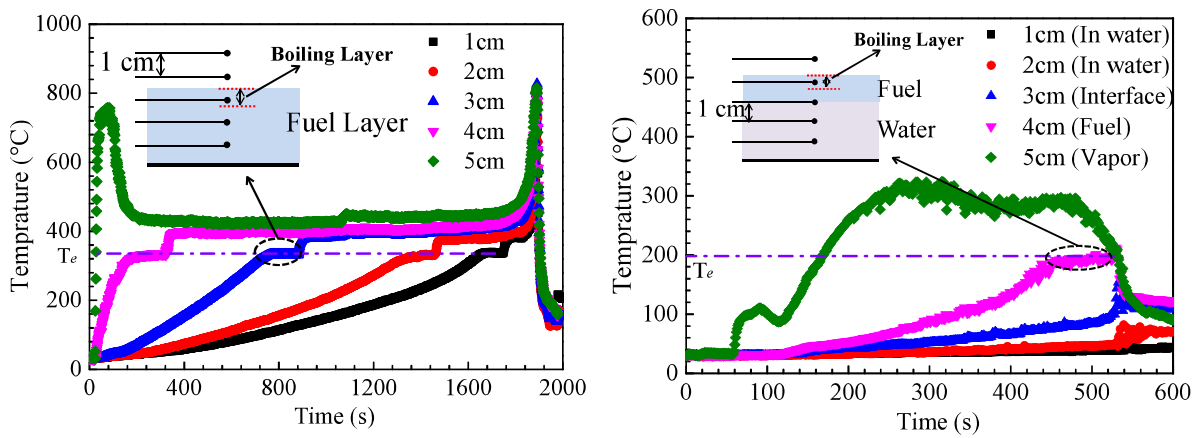

Fig. 8. The liquid fuel temperature as a function of time for Tests 3 and 5 
For Test 3 without the water layer, the fuel surface temperature can achieve around $340^{\circ} \mathrm{C}$ before evaporation, which corresponds to the fuel boiling point. However, for the fuel burning on the water surface, the temperature of the fuel surface can just reach around $200^{\circ} \mathrm{C}$. This phenomenon has also been observed in the other tests with a water layer. We believe that this is because the fuel is bound with water and form the oil-water mixture, which results in a lower boiling point (Strizhak et al., 2017; Tian et al., 2018). This is also consistent with the fact that cracking sound is present in all tests with a water layer. The decreasing temperature of the boiling layer reduces the heat transfer to the gradient layer, i.e., a decrease in the heat part $\left(\dot{q}_{\text {heat }}\right)$. Therefore, more heat feedback from the flame to fuel surface will be used to evaporate the fuel. Furthermore, the decrease in the surface temperature also indicates a reduction of re-radiation losses on the fuel surface. Both will result in a larger burning rate. It should be emphasized that the finding on the decrease in the boiling temperature for the burning of a thin fuel layer on a water surface is significant especially in the development of heat transfer models.

\subsection{The behaviors of boilover}

\subsubsection{The extinguishment after boilover}

As illustrated in Fig.3, the fire will suddenly extinguish after the violent boilover for burning of a relatively thick fuel layer. In burning of liquids, the formation of a boiling layer is important to sustain combustion, which is associated with the temperature profile of the liquid layer (Zhao et al., 2018; Vali et al., 2014). Fig.9 shows a comparison of the measured temperature before and after boilover for Tests 4 and 5 which have an initial fuel thickness of $3 \mathrm{~cm}$ and $2 \mathrm{~cm}$ respectively.
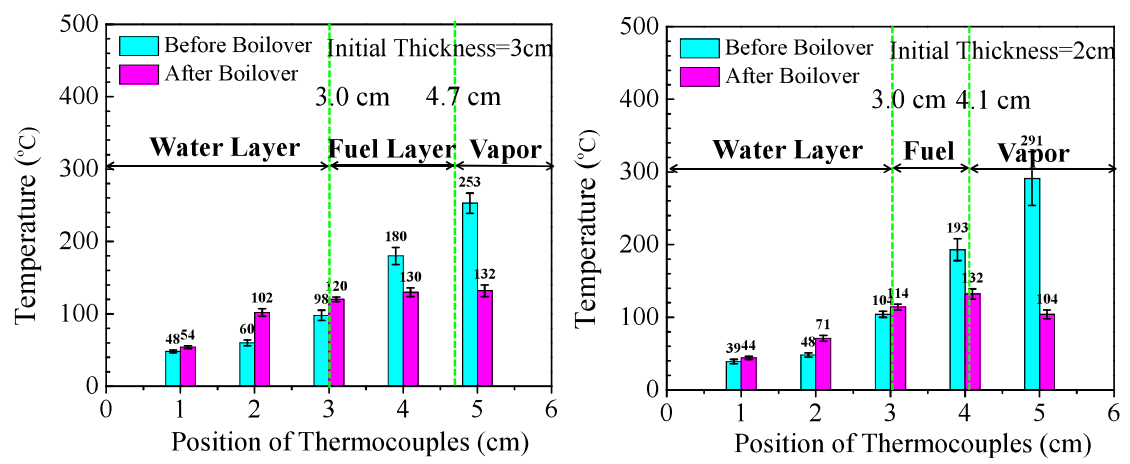
Fig. 9. The measured liquid temperature variation due to boilover for Tests 4 and 5

It can be seen in Fig. 9 that the fuel surface temperature will decrease quickly and the temperature in the liquid fuel will tend to become uniform. In previous studies, it was well known that a large amount of bubbles was produced during the boilover period (Laboureur et al., 2013; Garo et al., 1994). The moving bubbles increase heat convection, which results in uniform temperature. Following the destruction of the boiling layer, the burning rate and flame height will both decrease significantly, as seen pictures in Fig.4. In addition, the temperature at the interface between the water layer and the fuel layer is around $100^{\circ} \mathrm{C}$ before boilover. After the boilover, the temperature of interface surpassed the boiling point of water and achieved around $120^{\circ} \mathrm{C}$, which is in consistence with the observations in Garo's tests (1994). During boilover, the temperature of water in the upper layer also increases considerably, which illustrates the occurrence of violent heat convection between the water layer and the fuel layer. The temperature at $1 \mathrm{~cm}$ below the water surface increases from 60 to $102^{\circ} \mathrm{C}$ when boilover occurs compared to from 48 to $71^{\circ} \mathrm{C}$ in Test 5 . This further confirms that the heat convection intensity will increase with increasing initial fuel thickness. Based on the above analysis, we can conclude that the occurrence of boilover destroys the upper boiling layer and results in the strong convection in the gradient layer, which is the main reason behind the quick decay in the burning rate after boilover.

For the burning on the water surface, the flame size reduces significantly after the initial boilover. The small flame gradually disappears for the thick fuel layer burning, while it grows large again resulting in multiple occurrences of boilover for thin-layer burning. After the final boilover, the flame became very small (near extinguishment ) due to some local burning, meanwhile, a large amount of water vapor was recorded by the cameras. Therefore, the measured mass loss during this period can be approximately considered as the water mass loss. The water evaporation rate in this phase is calculated based on the measured mass loss and plotted against the initial fuel thickness in Fig.10. 


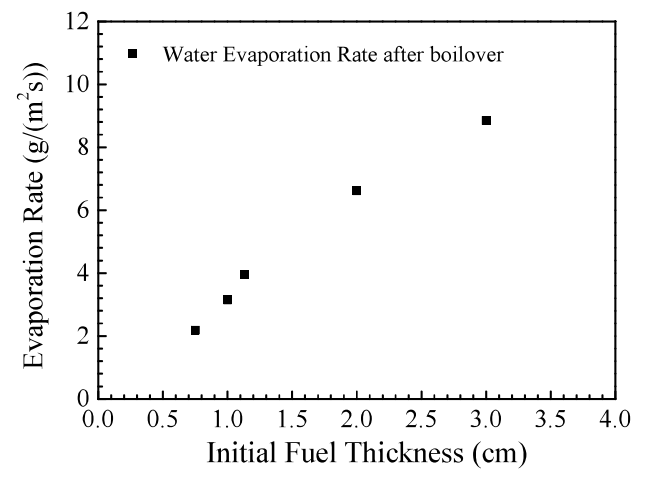

Fig. 10. The water evaporation rate as a function of initial fuel thickness

The evaporation rate increases almost linearly with the initial fuel thickness. The water evaporation rate depends on the heat transfer rate between the fuel layer and the water layer. In Fig.9, we observed that a thicker fuel layer results in a thicker water boiling layer, which contributes to a larger waster evaporation rate. The total amount of heat available from the fuel to vaporize the water can be expressed as:

$$
\mathrm{Q}=\int_{0}^{h} S c_{f}\left(T_{f}(x)-T_{b}\right) \rho_{f} d x
$$

where $S$ is the pool area. $\rho_{f}$ is the fuel density, $h$ is the fuel thickness at the start of boilover, $T_{b}$ is the water boiling point and $T_{f}(x)$ is the fuel temperature, which is a function of fuel thickness. After boilover, the temperature in the liquid layer can be approximately considered as uniform, regardless of liquid fuel thickness. After boilover, we found that the average fuel temperature is higher for the thick burning layer. So the storage heat $(Q)$ increased with increasing fuel thickness as shown in by Eq.(4) and subsequently sustain the evaporation for a longer time. This finding has been directly verified in the experiments because the duration of bubbles can be observed for a longer period for the thick layer burning experiments after extinguishment. As shown in (Zhou et al., 2019; Zhang et al., 2016) that the water vapor is an efficient fire extinguishing agent, the large and sustained water evaporation rate can effectively suppress burning, which explains why the small fire gradually extinguished for the thick layer burning after the boilover. On the contrary, the thin fuel layer will be cooled down in a shorter time by the strong convection between the fuel and water. It is difficult to continuously produce bubbles and the 
cooling of the fuel layer by water vapor is limited. Hence, the small fire can develop again and the continuous boilover can be observed for the thin-layer burning in the experiments.

\subsubsection{Boilover intensity}

Boilover intensity is a term used to indicate the significance of the boilover phenomenon with respect to the steady period before boilover onset (Kong et al., 2017; Koseki et al., 1991). The boilover intensity is defined by Koseki et al. (1991) as the ratio of the maximum mass burning rate during the boilover stage over the mass burning rate at the quasi-steady stage. Because of uncertainly of the maximum burning rate, the averaged burning rate during the boilover period is often used to substitute the maximum burning rate (Ferrero et al., 2007; Kong et al., 2017; Garo et al., 1999). In addition, the irradiance variation at the position of $L / D=5$ can also be used to express the boilover intensity (Koseki et al., 1991), Eq. (6). In this work, both parameters are used to characterize the boilover intensity.

$$
\begin{gathered}
I_{b \mathrm{~m}}=\frac{m_{a b}^{\prime}}{m_{s}^{\prime}} \\
I_{b \mathrm{~m}}^{\prime}=\frac{q_{b r}}{q_{s r}}
\end{gathered}
$$

where $m_{a b}^{\prime}$ is average burning rate during the boilover period; $m_{s}^{\prime}$ is the steady burning rate; $q_{b r}$ and $q_{s r}$ are the measured maximum irradiance and steady irradiance at the position of $\mathrm{L} / \mathrm{D}=5$, respectively. Fig.11 shows the boilover intensity variation with the initial fuel thickness. For the thin layer burning cases (5 and 7.5 $\mathrm{mm})$, both the intensity of the initial boilover and maximum intensity are presented.
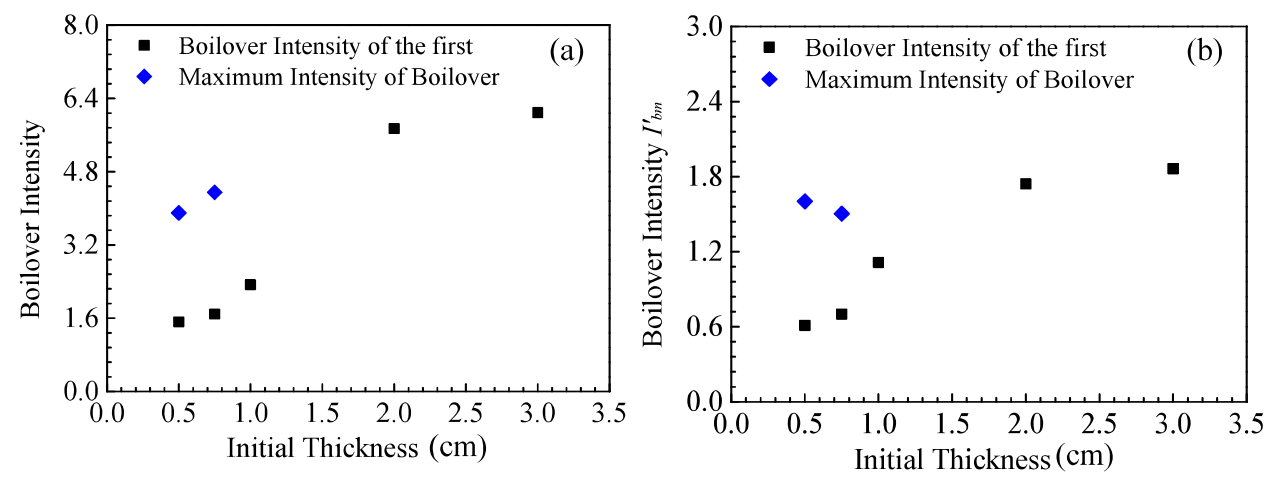

Fig. 11. The boilover intensity as a function of initial fuel thickness based on a) 
burning rate and $b$ ) irradiance

The boilover intensity calculated based on the burning rate is systemically larger than that from the irradiance $(\mathrm{L} / \mathrm{D}=5)$, although the variation trends are similar for both methods. Fig.11 clearly shows that the first boilover intensity increases with the increasing initial fuel thickness. This is because the convection heat transfer between the fuel layer and the water layer is more violent for the thick layer burning, which produces more bubbles. The broken bubbles at the fuel surface will result in the splash behavior and more fuels can be thrown into the flame. However, the increasing rate of boilover intensity gradually decreases with the increase of the initial fuel thickness. As we have known that the fuel layer can be divided into two layers: boiling layer and gradient layer in vertical direction (Vali et al., 2014; Zhao et al., 2018). The boiling layer refers to the fuel top layer and the corresponding thickness is a constant, which is related to the radiative absorption (Zhao et al., 2018). So the distance from the water surface to the boiling layer actually increases with the increase of fuel thickness, which will limit the convection intensity. Furthermore, we can observe that the maximum boilover intensity of thin layer burning can overpass that of thick layer burning for some cases as shown in Fig.11. This is because the water layer was heated continuously for the multiple short boilovers. So one of the short boilover for the thin fuel burning maybe overpass that of thick layer burning

\subsubsection{Time to boilover onset}

It has been shown that thin-layer boilover starts when the temperature at the fuelwater interface reaches the water boiling point (Laboureur et al., 2013; Garo et al., 1994). Therefore, it is a key to determine the temperature at the interface between the fuel layer and the water layer. Figure 12 shows the measured temperature at the fuelwater interface for four cases with varying initial fuel thickness. 


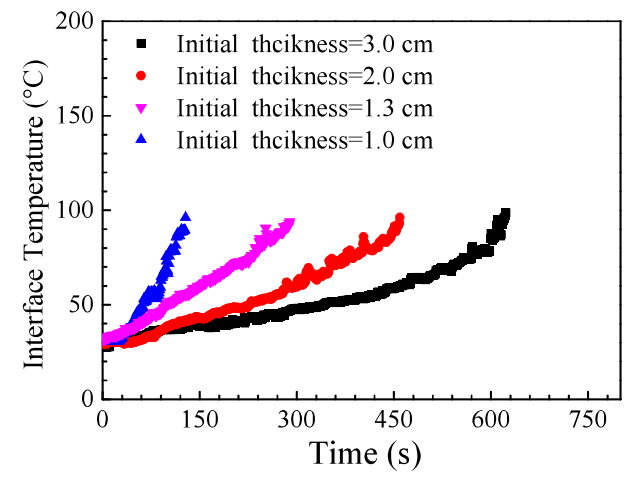

Fig. 12. The interface temperature as a function of time

The interface temperature increases almost linearly with time. For the thin-layer burning on a water layer, the heat transfer before boilover is mainly by heat conduction in the gradient layer. One-dimensional transient heat transfer equation is widely used to analyze the temperature profile in liquid layer (Arai et al., 1990; Garo et al., 1999; Inamura et al., 1992). In the detailed calculation of the temperature profile in the liquid layer, Garo et al (1999) also found that the temperature increase rate at the interface can be considered as a linear relation when the fuel thickness is more than $8 \mathrm{~mm}$ and a simple model to predict the time to boilover (Garo et al., 1999; Kong et al., 2017; Ferrero et al., 2006).

$$
t_{b}=a h_{0}-b
$$

where $a$ and $\mathrm{b}$ are constants, which can be determined by experimental data, $h_{0}$ is the initial fuel thickness. Fig.13 presents the time to boilover obtained in this study and those by Garo et al. (1999) and Ferrero et al. (2006), for heating oil and Diesel respectively, as a function of initial fuel thickness.

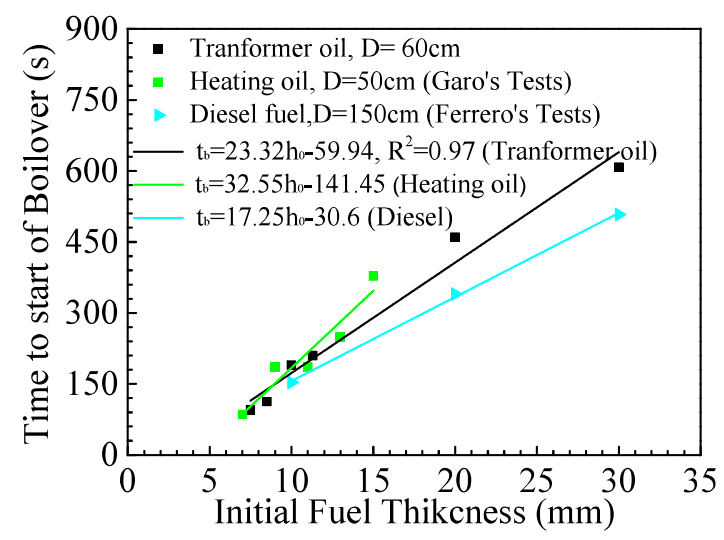


Fig. 13. Time to boilover versus initial fuel thickness

Figure 13 confirms that there is a linear relation between the time to boilover of transformer oil and the initial fuel thickness, consistent with the finding for Heating Oil and Diesel. The best fit of the experimental data results in the following relation with a correlation coefficient of 0.97 .

$$
t_{b}=23.32 h_{o}-59.94
$$

Clearly, the relation depends on the fuel properties and burning scale. By analysis of one-dimensional transient heat transfer, we can see the heat transfer rate is closely related to the fuel boiling point and thermal diffusivity. For different fuels, these parameters vary obviously, which determines the heat transfer rate in the liquid layer. On the other hand, the heat feedback from the flame to the fuel surface will also change with the variation of pool diameter. For example, the heat conduction from the side wall to the liquid plays an important role in the pool fire burning with a diameter of $10 \mathrm{~cm}$ (Tao et al., 2013). However, this part can be neglected for the large scale pool fires (Hamins et al., 1994). The variation of heat feedback from the flame will also affect the heat transfer process in the liquid layer. As a result, more experiments with different sizes and fuels should be conducted before practical applications.

\section{Conclusion}

This study was aimed at identifying the burning characteristics of the thin-layer transformer oil pool fires on a water surface. To this end, a series of transformer oil pool fires was performed with different initial fuel thicknesses. The burning process, burning rate, flame height, liquid temperature and boilover phenomenon were measured and analyzed. The main results are as follows:

- For liquid fuel burning on a water surface, the whole burning process can be divided into the five burning phases: (I) rapid growth burning, (II) steady burning, (III) short boilover burning, (IV) continuous boilover burning and (V) fire decay. The occurrence of the middle three phases (II, III, IV) is closely related to the initial fuel thickness. The steady burning rate on a water surface is slightly larger than that without a water layer due to the decrease of boiling temperature of fuel- 
water mixture. Moreover, the burning efficiency varies significantly between thinand thick-layer burning.

- During the boilover period, the burning rate, flame size and radiation all increases considerably compared with those during steady burning. After the initial boilover, the burning rate and the flame size all become very small because of destruction of the boiling layer by the produced water bubbles. For thick layer burning, this is followed by extinguishment whereas for thin layer burning, the fire grows against followed by multiple occurrences of boilover. The critical fuel thickness was found to be $7.5 \sim 10 \mathrm{~mm}$, which determines the occurrence of one time boilover or multiple short boilover. This difference is attributed to the production of water bubbles and the continuous vapor, which suppress the fire.

- The intensity of the first boilover was found to increase with the increasing initial fuel thickness. However, the increasing rate reduces as the fuel thickness increases indicating that the intensity of the boilover may approaches a constant if the fuel thickness is sufficiently large. For thin-layer burning, the maximum boilover intensity can overpass that of thick-layer burning in some cases. As a result, particularly attention should be paid to thin-layer boilover during firefighting.

- The time to boilover increases with the increasing initial fuel thickness and there is a linear relation between the time to boilover and initial fuel thickness for the present study using transformer oils, which agrees with the findings in the literature for heating oil and diesel. The fact that the different relation obtained in this work indicates that it depends on the fuel properties as well as on the size of the fire.

The present study can help increase the understanding of the burning process of liquid fuels on a water layer, particularly for the burning behaviors after the initial boilover. Furthermore, the importance of the initial fuel thickness on the thin-layer boilover has been displayed. More importantly, it can enrich the basic experimental data of thin-layer transformer oil burning on a water surface. These results and fundamental analysis will lay a solid foundation for future studies on the situ-burning and thermal hazard assessment for leakage fires accidents. 


\section{Acknowledgements}

This study was sponsored by the National Key R\&D Program of China ( No. 2018YFC0808100), the National Natural Science Foundation of China (No. 51906253) and the Opening Funds of State Key Laboratory of Building Safety and

Built Environment and National Engineering Research Center of Building Technology (BSBE 2017-03).

\section{References}

Alva, U.Rojas, Andersen1, B.S, Jomaas, G., 2018. Pumice Stones as Potential in-Situ Burning Enhancer. Cold Reg. Sci. Technol. 146:. 167-174.

Arai, M., Saito, K., Altenkirch, R.A.,1990. A study of boilover in liquid pool fires supported on water part I: effects of a water sublayer on pool fires. Combust. Sci. Technol. 71, 25-40.

Brogaard, N., Sørensen, M., Fritt-Rasmussen, J., et al., 2014. A new experimental rig for oil burning on water-results for crude and pure oils. Fire Safety Science 11: 1481-1495.

Buist, I., McCourt, J., Potter, S., et al., 1999. In situ burning. Pure Appl. Chem. 71(1), 43-65.

Bullock, R.J., Perkins, R.A., Aggarwal, S., 2019. In-situ burning with chemical herders for Arctic oil spill response: Meta-analysis and review. Sci. Total Environ. 675, 705-716.

Chatris, J.M., Quintela, J., Folch, J., et al., 2001. Experimental study of burning rate in hydrocarbon pool fires. Combust. Flame 126(1-2), 1373-1383.

Drysdale, D., 2011. An introduction to fire dynamics. John Wiley \& Sons.

Fan, W.C., Sun, J., Liao, G., 1995. Experimental study on the premonitory phenomena of boilover in liquid pool fires supported on water. J. Loss Prev. Process Ind. 8(4), 221-227.

Farahani, H.F., Jomaas, G., Rangwala, A.S., 2015. Effects of convective motion in n- 
octane pool fires in an ice cavity. Combust. Flame 162(12), 4643-4648.

Ferrero, F., Muñoz, M., Kozanoglu, B., et al., 2006. Experimental study of thin-layer boilover in large-scale pool fires. J. Hazard. Mater. 137(3), 1293-1302.

Ferrero, F., Muñoz, M., Arnaldos. J., 2007. Thin-layer boilover in diesel-oil fires: Determining the increase of thermal hazards and safety distances. J. Hazard. Mater. 140(1-2), 361-368.

Fingas, M.F., Punt, M., 2000. In-situ burning: a cleanup technique for oil spills on water. Emergencies Science Division, Environmental Technology Centre.

Fritt-Rasmussen, J., Brandvik, P.J., 2011. Measuring ignitability for in situ burning of oil spills weathered under Arctic conditions: From laboratory studies to largescale field experiments. Mar. Pollut. Bull. 62(8), 1780-1785.

Fritt-Rasmussen, J., Ascanius, B.E., Brandvik, P.J., et al., 2013. Composition of in situ burn residue as a function of weathering conditions. Mar. Pollut. Bull. 67(12), $75-81$.

Garo, J.P., Vantelon, J.P., Fernandez-Pello, A.C., 1994. Boilover burning of oil spilled on water. Combustion Inst. 25(1), 1481-1488.

Garo, J.P., Gillard, P., Vantelon, J.P., et al., 1999. Combustion of liquid fuels spilled on water. Prediction of time to start of boilover. Combust. Sci. Technol. 147(1-6), 39-59.

Hamins, A., Fischer, S.J., Kashiwagi, T., et al., 1994. Heat feedback to the fuel surface in pool fires. Combust. Sci. Technol. 97(1-3), 37-62.

Hristov, J., Planas-Cuchi, E., Arnaldos, J., et al., 2004. Accidental burning of a fuel layer on a waterbed: a scale analysis of the models predicting the pre-boilover time and tests to published data. Int. J. Therm. Sci. 43(3), 221-239.

Inamura, T., Saito, K., Tagavi, K.A., 1992. A study of boilover in liquid pool fires supported on water. Part II: Effects of in-depth radiation absorption. Combust. Sci. Technol. 86(1-6), 105-119.

Kong, D., Liu, P., Zhang, J., et al., 2017. Small scale experiment study on the characteristics of boilover. J. Loss Prev. Process Ind. 48, 101-110.

Kong, D., He, X., Yang, H., et al., 2019. Experimental study for flame base drag and 
burning efficiency of spilled crude oil during in-situ burning on water. Process. Saf. Environ. 131, 48-54.

Koseki, H., Kokkala, M.A., Mulholland, G.W., 1991. Experimental study of boilover in crude oil fires. F. S. S. 3, 865-874.

Koseki, H., Natsume, Y., Iwata, Y., et al., 2006. Large-scale boilover experiments using crude oil. Fire Safety J. 41(7), 529-535.

Kozanoglu, B., Ferrero, F., Muñoz, M., et al., 2008. Thermal analysis of thin layer boilover. Heat and mass transfer 44(12), 1549-1555.

Laboureur, D., Aprin, L., Osmont, A., et al., 2013. Small scale thin-layer boilover experiments: Physical understanding and modeling of the water sub-layer boiling and the flame enlargement. J. Loss Prev. Process Ind. 26(6), 1380-1389.

Li, Y., Huang, H., Wang, Z., et al., 2015. An experimental and modeling study of continuous liquid fuel spill fires on water. J. Loss Prev. Process Ind. 33, 250-257.

Ping, P., He, X., Kong, D., et al., 2018. An experimental investigation of burning rate and flame tilt of the boilover fire under cross air flows. Appl. Therm. Eng. 133, 501-511.

Rojas-Alva, U., Andersen, B.S., Jomaas, G., 2019. Chemical herding of weathered crude oils for in-situ burning. J. Environ. Mange. 250, 109470.

Sivagami, K., Vignesh, V.J., Tamizhdurai, P., et al., 2019. Studies on short term weathering of spilled oil along Chennai coast in South India. J. Clean Prod. 230, 1410-1420.

Strizhak, P.A., Piskunov, M.V., Volkov, R.S., et al., 2017. Evaporation, boiling and explosive breakup of oil-water emulsion drops under intense radiant heating. Chem. Eng. Res. Des. 127: 72-80.

Suo-Anttila, J.M., Blanchat, T.K., Ricks, A.J., et al., 2009. Characterization of thermal radiation spectra in $2 \mathrm{~m}$ pool fires. Combustion Inst. 32(2), 2567-2574.

Tao, C., He, Y., Li, Y., et al., 2013. Effects of oblique air flow on burning rates of square ethanol pool fires. J. Hazard. Mater. 260, 552-562.

Tao, Y., Lu, K., Chen, X., et al., 2020. Experimental investigation on the temperature profile of large scale RP-5 aviation kerosene pool fire in an open space. Fuel 264, 
116852.

Tian, X, Zhong, M, Shi, C, et al., 2018. Experimental study of the combustion characteristics of methanol-gasoline blends pool fires in a full-scale tunnel. Fire Mater. 42(4), 386-393.

Twardus, E.M., Brzustowski, T.A., 1981. The burning of crude oil spilled on water. Archivum Combustionis 1(1/2), 49-60.

Vali, A., Nobes, D.S., Kostiuk, L.W., 2014. Transport phenomena within the liquid phase of a laboratory-scale circular methanol pool fire. Combust. Flame 161(4), 1076-1084.

van Gelderen, L., Brogaard, N.L., Sørensen, M.X., et al., 2015. Importance of the slick thickness for effective in-situ burning of crude oil. Fire Safety J. 78, 1-9.

Xiao, H., Gollner, M.J., Oran, E.S., 2016. From fire whirls to blue whirls and combustion with reduced pollution. P. Natl. Acad. of Sci., 113(34): 9457-9462.

Zhao, J., Huang, H., Li, Y., et al., 2016. Experimental and modeling study of the behavior of a large-scale spill fire on a water layer. J. Loss Prev. Process Ind. 43, $514-520$.

Zhao, J., Huang, H., Jomaas, G., et al., 2018. Experimental study of the burning behaviors of thin-layer pool fires. Combust. Flame 193, 327-334.

Zhao, J., Zhu, H., Huang, H., et al., 2019. Experimental study on the liquid layer spread and burning behaviors of continuous heptane spill fires. Process. Saf. Environ. 122, 320-327.

Zhang, P., Tang, X., Tian, X., et al., 2016. Experimental study on the interaction between fire and water mist in long and narrow spaces. Appl. Therm. Eng. 94: 706-714. 


\section{Declaration of Interest Statement}

The authors declare there are no conflicts of interest regarding the publication of this paper. 